\title{
DRAINAGE AND SIPHONING OF A KARSTIC SPRING: A CASE STUDY
}

\author{
E. Sanz*, P. Rosas, and I. MenÉndez-Pidal, \\ Applied Geology Laboratory. Engineering Geology Department. Esc. Téc. Sup. de Ingenieros de Caminos, C. and P. \\ c/ Profesor Aranguren s/n. Ciudad Universitaria 28040 Madrid. Spain
}

\begin{abstract}
The Fuentetoba Spring, with a mean flow of $210 \mathrm{~L} \mathrm{~s}^{-1}$, releases the discharge from an aquifer that comprises three hydraulically-connected synclines. The spring has a very irregular flow of between $8 \mathrm{~L} \mathrm{~s}^{-1}$ and $3,400 \mathrm{~L} \mathrm{~s}^{-1}$ due to the predominant water circulation that is non-Darcian turbulent flow as an underground torrent in the vadose zone, as well as through well-developed karstic conduits in the phreatic and epiphreatic zones, as attested to by speleological explorations. The long response times to recharge by the Fuentetoba karstic system, seen in the spring's hydrograph, are controlled by regional factors. Nevertheless, certain responses that have very long time lags under high water conditions might be governed in the final stretch of the flowpath by mechanisms of pressure or siphoning of the floodwave, and perhaps by constrictions or plugs of sediment in the conduits.
\end{abstract}

\section{INTRODUCTION AND OBJECTIVES}

The analysis of flow variation in springs is important for two reasons. The quantification and prediction of spring flow is an essential prerequisite for managing groundwater resources in an aquifer, and the intensity, duration, and nature of precipitation are the variables that most influence the shape of the hydrograph. Analysis of flow variations can elucidate some of the characteristics of the aquifer that influence the relation between recharge and discharge of water: the different flow states, storage, inertia, and flow recession, and their relationship with structural geological features. Spring discharge is dependent on catchment characteristics such as size and slope, recharge style, drainage network density, geological variability, vegetation, and soil (Ford and Williams, 2007).

The temporal distribution of natural recharge and corresponding transit time of the water through karst aquifers can be a complicated issue since, in addition to depending on the intensity and duration of the recharge events, as well as the antecedent soil moisture, it depends on the existence of significant heterogeneity in the conduits' geometry and connections between them, and on the hydraulic parameters of the vadose and phreatic zones (Halihan and Wicks, 1998, Geyer et al. 2008).

Karst flow is usually subdivided into conduit flow, fracture flow, and matrix flow. Rapid responses in the hydrograph under high flow conditions are usually explained by conduit flow and fracture flow. The beginning segment of the recession curve and its steeper slope are usually explained by drainage through fractures and the rock matrix, while only the transmissivity of the matrix plays a part in the shallower slopes of the recession curve when the flow is very slow (Shevenell, 1996). However, the phreatic and epiphreatic conditions can change over time, and the geometry of the groundwater flow may change depending on the particular conduits that are used under high- or low-water conditions.
All these factors can lead to a situation where the temporal distribution of the discharge does not exactly correspond to the recharge. This has been observed in certain karst systems, particularly during periods of high water and storm events. Various possible mechanisms are cited to explain this type of hydrograph.

The flow of some karst springs can rapidly change from slight or absent to very great. This effect can be explained by the impulsion under pressure that occurs during periods of high recharge to old, ponded water that is stored close to the spring. This phenomenon has been observed in several karst systems (Yevjevich, 1981). Other intermittent phenomena are explained by the existence of a siphon that operates only under high-water conditions when the groundwater level lies above the mouth of the outlet. In other cases, the siphon can operate along an outflow conduit, carrying the ordinary groundwater flows that are ponded up in a reservoir behind the spring. When the water reaches the mouth, all the water that was stored in the reservoir is expelled due to the vacuum created. There are many examples of springs associated with siphons (Milanovic, 2007). The phenomenon of siphoning (i.e., regular evacuation through an inverted U-tube) occurs only in very special cases, such as at the source of the river Mundo in Spain (Rodríguez-Estrella et al., 2002). Mangin (1974) studied the intermittent phenomena and made numerous experiments using small-scale models. Other unusual cases have been cited, such as Gelodareh Spring (Iran), where the existence of a siphon-flow system explains the multiple periodic peaks of the breakthrough curve and the lack of tails (Karimi and Ashjari, 2009).

Sara (1977) and Urzendowsky (1993) explained that in Big Spring in Kings Canyon National Park a sediment plug exists that blocks flow through the main outflow conduit. Under high-water conditions this blockage is released when the water

\footnotetext{
* Corresponding author: esanz@caminos.upm.es
} 
level behind it rises and produces a sufficient hydraulic head to remobilize the deposits and allowing for the evacuation of the water impounded behind them. As the water level falls, sediment deposition begins again, and the conduit is plugged, so continuing the cycle. Halihan et al. (1998) explain that drainage in the Devil's Cave system during storm events is governed by the presence of constrictions in the network of conduits, and they were able to model the hydrograph of the outlet spring in a satisfactory manner by considering a reservoir/constriction model.

The case studied in this paper is the karst system of Pico Frentes, in the Spanish Iberian Range. This system, draining through the Fuentetoba Spring, has a catchment of approximately $26 \mathrm{~km}^{2}$ that is the object of our investigation (Fig. 1). It is currently used to supply water to a small village and various groups of houses. The Fuentetoba karst system is an unconfined karst aquifer. It is geometrically well-defined, opening the opportunity to make direct observations of the active and abandoned conduits in the unsaturated zone within the stream caves by means of conventional caving. We also accessed the phreatic conduit of the Fuentetoba spring, as well as the underground river in the cave associated with this spring, by cave diving. These investigations showed us what the karstic aquifer is really like inside, albeit in a partial and incomplete way. The recent exploration (Sanz Pérez et al., 2012) of these apparently independent cavities that converge at the Fuentetoba Spring increases the chances of elucidating the drainage from this karstic system, even though we are dealing with fragments of conduit networks that must belong to a much larger subterranean drainage system.

The organization of these conduits is comparable to the drainage network of a surface river system (Bakalowicz, 2005). Flow in a karstic aquifer exhibits a double (or triple) system, characterized by the interaction of the diffuse and conduit domains. In the conduits, flow can be rapid (Shuster and White, 1971; Atkinson, 1977). The flow in the conduits can be laminar or turbulent, depending on the Reynold's number. In karstic aquifers drained by large springs, the flow is usually organized in high-permeability channel networks (Worthington and Ford, 2009), which are suited to mathematical modelling (Worthington, 1999, 2009).

The aim of this investigation was to analyze the drainage of Fuentetoba Spring and the variable response of the aquifer to recharge, especially in situations where siphoning occurs. In this respect, hydrograph analysis, tracer tests, and direct observations of the cave hydrology were all useful.

\section{Methods}

Karstic aquifers have unique characteristics and a complexity that differentiates them from other types of aquifers. This means that the classical hydrogeological research approach may be inappropriate or insufficient (Bakalowicz, 2005). Specific techniques are required to explore and study them (White, 2002 and 2003; Ford and Williams, 2007; Goldscheider and Andreo, 2007).

In the case of Fuentetoba Spring, the presence of only one borehole in the entire aquifer limits many aspects of hydrogeological understanding. However, a hydrogeological study to define the aquifer and quantify the flow from its springs, along with the establishment of a water balance using a mathematical rainfall-runoff model, has led to a basic understanding of this karstic aquifer (Rosas et al., 2016). Using this prior knowledge of the specific characteristics together with available information resources, we applied and combined the methods outlined below to advance the understanding of this karstic drainage system.

A gauging station was installed to measure the spring flow at Fuentetoba Spring over the hydrological years of 2010-11 and 2011-12. The spring was gauged along the discharge stream. The calibration curve for the gauging station was established by direct gauging using flowmeters under various hydrological situations, resulting in a known relation between water levels and flow. The hydrograph of Fuentetoba Spring was analyzed. Tracer tests can be done (for example, Käss, W, 1998; Geyer et al., 2007; Benischke et al., 2007; Perrin and Luetscher, 2008; Goldscheider et al., 2008; Segovia et al., 2011) to characterize local hydrogeological properties, such as the possible effect of siphoning or lags in flow. In the case of Fuentetoba Spring, three tracer tests were performed in 2012 and 2013 during low-water periods that were followed by recharge events, using uranine, together with point injections of $\mathrm{NaCl}$. The injection point was in the subterranean river $3,000 \mathrm{~m}$ straight-line distance from Fuentetoba Spring, specifically in the final stretch where it flows through a syncline that exhibits a unique hydrogeological behavior.

Less conventional methods, such as direct mapping by cave divers and conventional caving and mapping of the conduit network were used both in the epiphreatic and the saturated zones. These techniques allowed us to better understand the hydrological functioning of the karst medium and certain peculiarities of this system. These speleological surveys were undertaken over the last four years under various hydrological conditions. Numerous speleological explorations and topographical surveys were done in the $3,000 \mathrm{~m}$ stretch that is currently known of the Majada del Cura Cave network. These expeditions included point gauging of the subterranean river under both high and low water situations (Fig 1). Four cave diving surveys were completed in the underwater parts of the Majada del Cura cave network (Figs. 1 and 2). Five cave diving surveys were made in the outflow conduit of Fuentetoba Spring (Fig. 3). Further time was spent looking for new access routes into the other conduits between the underground river and Fuentetoba Spring, either by detailed surveys of existing potholes or looking for new caves. A description of this conduit network is included in the section Description of the Study Area, while the hydrological observations are included in the Results section. 


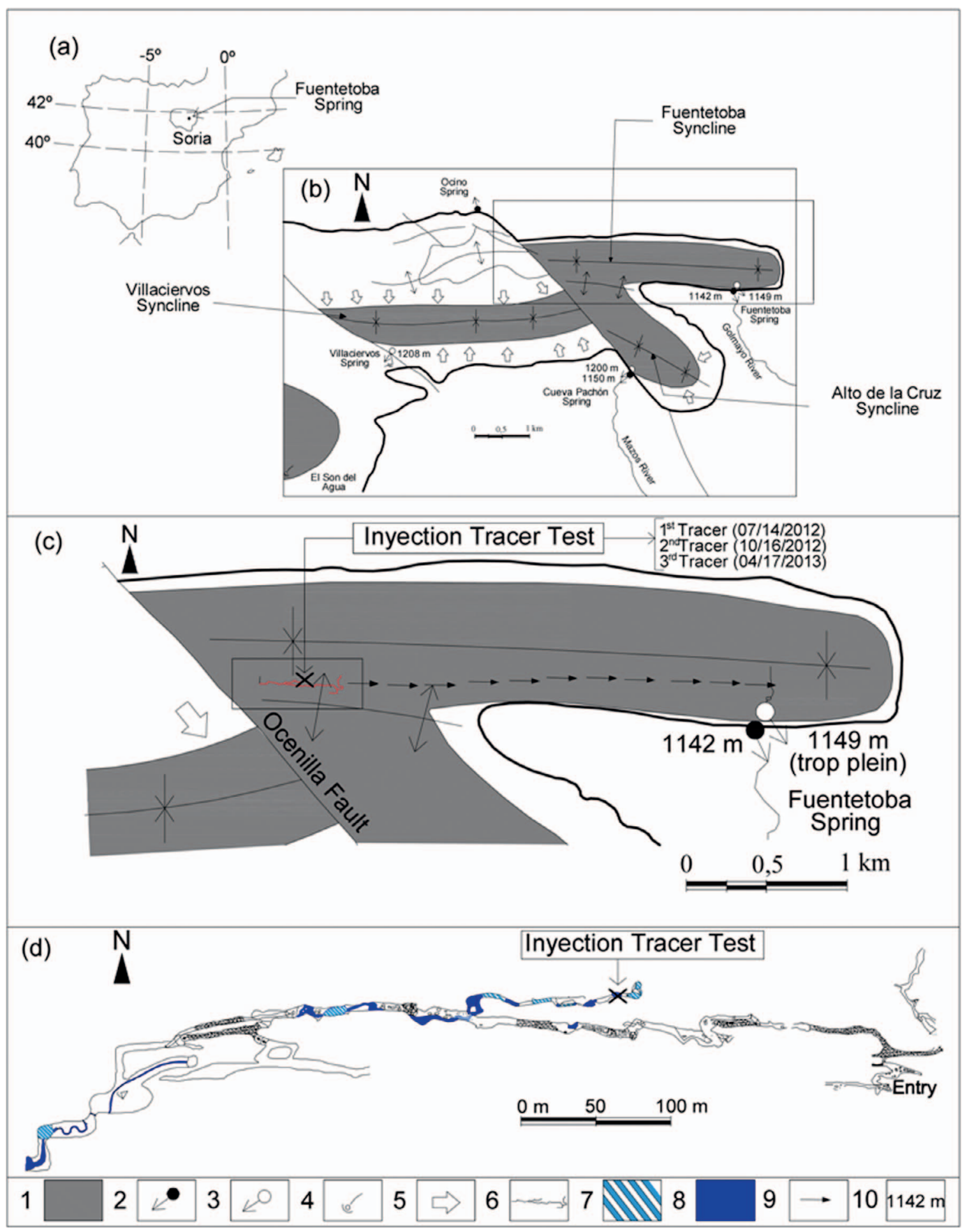

Figure 1. (a) Location of the study zone. (b) Karst system of Fuentetoba Spring. (c) Network of explored underground river and groundwater path confirmed by tracer studies in the Fuentetoba syncline. (d) Detail plan view of the conduits and galleries of the underground river. 1. Outcrop of the limestone-marl contact. 2. Permanent spring. 3. Overflow spring. 4. Ephemeral spring. 5. Lateral recharge in unsaturated zone of the syncline flanks. 6. Network of explored galleries of the underground river. 7. Siphons. 8. Underground river. 9. Flow of groundwater confirmed using tracers. 10. Elevation in meters. 


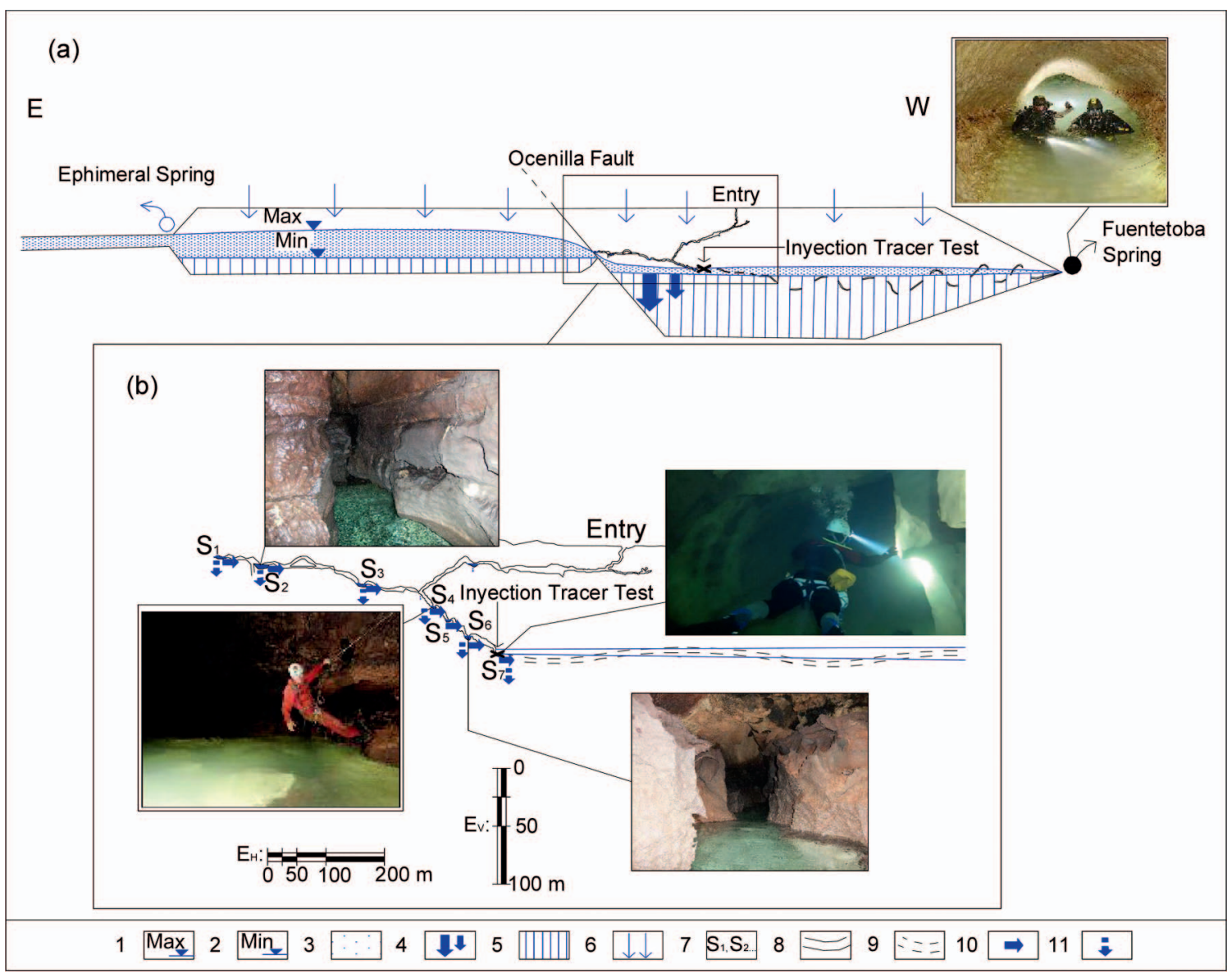

Figure 2. A. (a) Schematic hydrogeological section running east-west. (b) Profile of network of explored and inferred conduits of the underground river that emerges at the Fuentetoba Spring. 1. Maximum phreatic level. 2. Minimum phreatic level. 3. Epiphreatic zone. 4. Flow under pressure during high-water. 5. Permanent reserves. 6. Natural recharge. 7. Siphons [sumps] explored by divers. 8. Network of explored conduits. 9. Schematic and inferred network of conduits. 10. Flow direction of underground river. 11. Filtrations in the underground river.

\section{Description of the Study Area}

\section{Climate and Vegetation}

The climate of this area is Mediterranean, with a relatively cold winter and an average annual rainfall of $574 \mathrm{~mm}$, peaking in the spring. The spatial distribution of rainfall on the plateau is very uniform, and it is not uncommon for winter precipitation to fall as snow. The harsh continental climatic conditions of the area, the impoverished soils that are unfit for cultivation, and the large infiltration capacity of the karst gives the plateau its marked aridity that has conserved the extensive woodlands of Spanish Juniper (Juniperus thurifera), this being one of the trees most resistant to such conditions.

\section{Stratigraphy and Tectonic Structures}

From a stratigraphic point of view, the oldest deposits in the area belong to the Weald Facies and comprise conglomerates, sands, limonites, and purple clays. Altogether, this series can exceed $200 \mathrm{~m}$ thick. Above it lies the Albian
Utrillas Facies, consisting of $150 \mathrm{~m}$ siliceous, terrigenous deposits in a white kaoliniferous matrix. Above these are fossil marls from the Cenomanian and Turonian, reaching 101 $m$ thick. The upper part of the Turonian and the ConiacianSantonan-Campanian comprise some $200 \mathrm{~m}$ of nodular limestones (IGME, 1980, 1982 and Navarro, 1991), which project upwards to form the scarps along the northern edge of the sierra, such as Pico Frentes. Overlying these series and concordant with the earlier geological formations are the Garumnian facies, already transitioning into the Tertiary (Fig. $3)$.

Structurally, the folds, which were generated during the Alpine Orogeny, follow an east-west alignment. There is a large asymmetrical syncline, the Villaciervos syncline, whose northern limb dips gently and is more developed than the southern limb. Beyond, to the northeast, is a small anticline. This succession of folds has been displaced by the Ocenilla Fault. This fault is a dextral strike-slip fault with a horizontal displacement of $1,500 \mathrm{~m}$, though it also has a vertical 


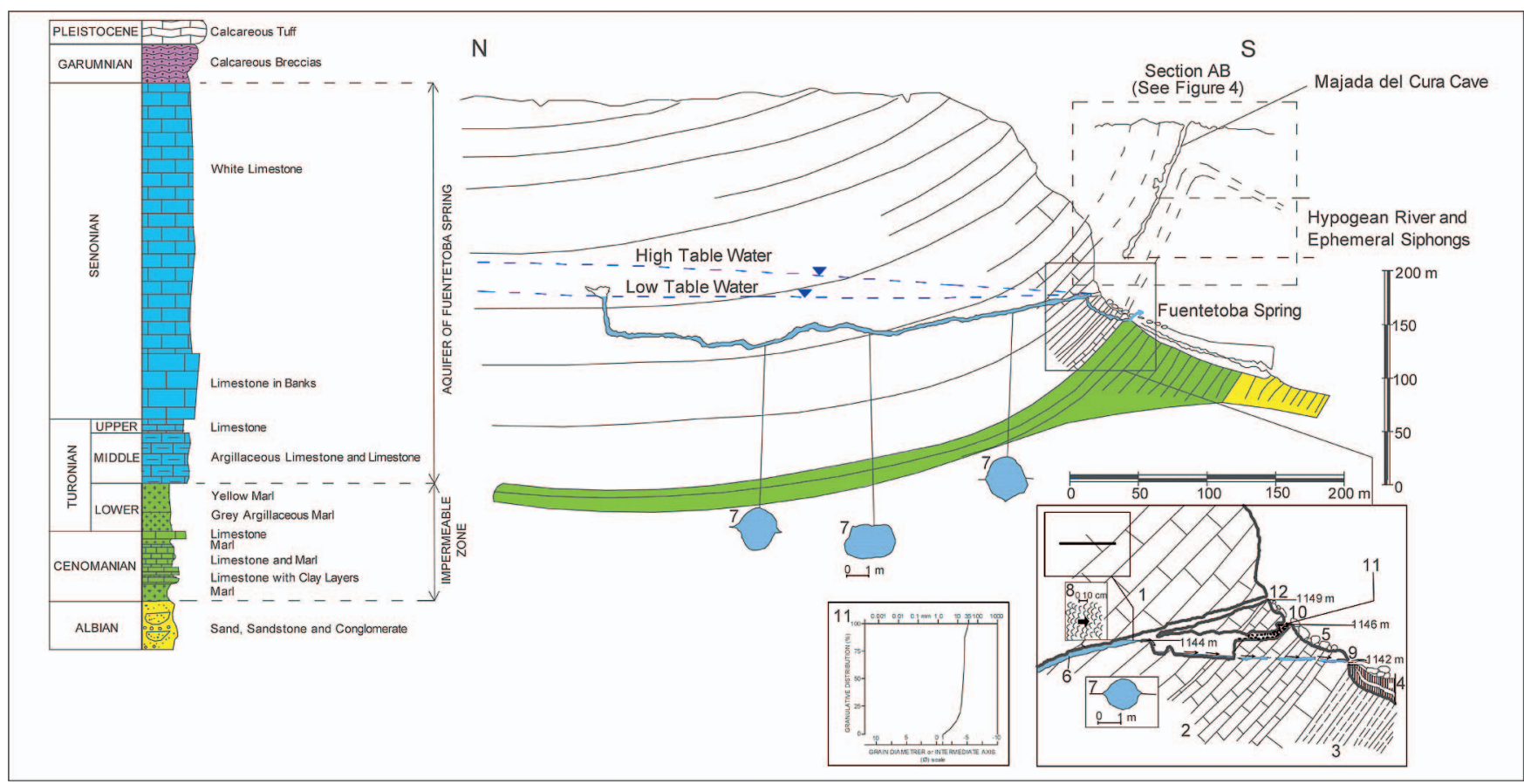

Figure 3. Conduit of the Fuentetoba Spring and stratigraphic column in the Fuentetoba Syncline Aquifer. 1. Limestone in banks. 2. Limestone. 3. Marl. 4. Tufa. 5. Blocks. 6. Conduit. 7. Conduit section. 8. Scallops. 9. Spring. 10. Lower spring overflow. 11. Granulative distribution. 12. Upper spring overflow.

displacement of $40 \mathrm{~m}$, as deduced from the structure contours, and the sunken block is the eastern one. Beyond the Ocenilla Fault, from north to south, are three folds: the Pico Frentes or Fuentetoba Syncline, followed by an anticline with steep limbs, and finally the syncline of the Sierra de La Llana and Alto de Peña Cruz, along whose southern edge emerges the Cueva Pachón Spring (Figs. 1 and 4). Fuentetoba Spring, meanwhile, emerges on the southern edge of the northern syncline.

The Coniacian-Santonan-Campanian limestones make up a clearly permeable hydrostratigraphic layer of considerable thickness that overlies low-permeability marls. The Weald and Utrillas facies are considered to be of low to moderate permeability (Fig. 3).

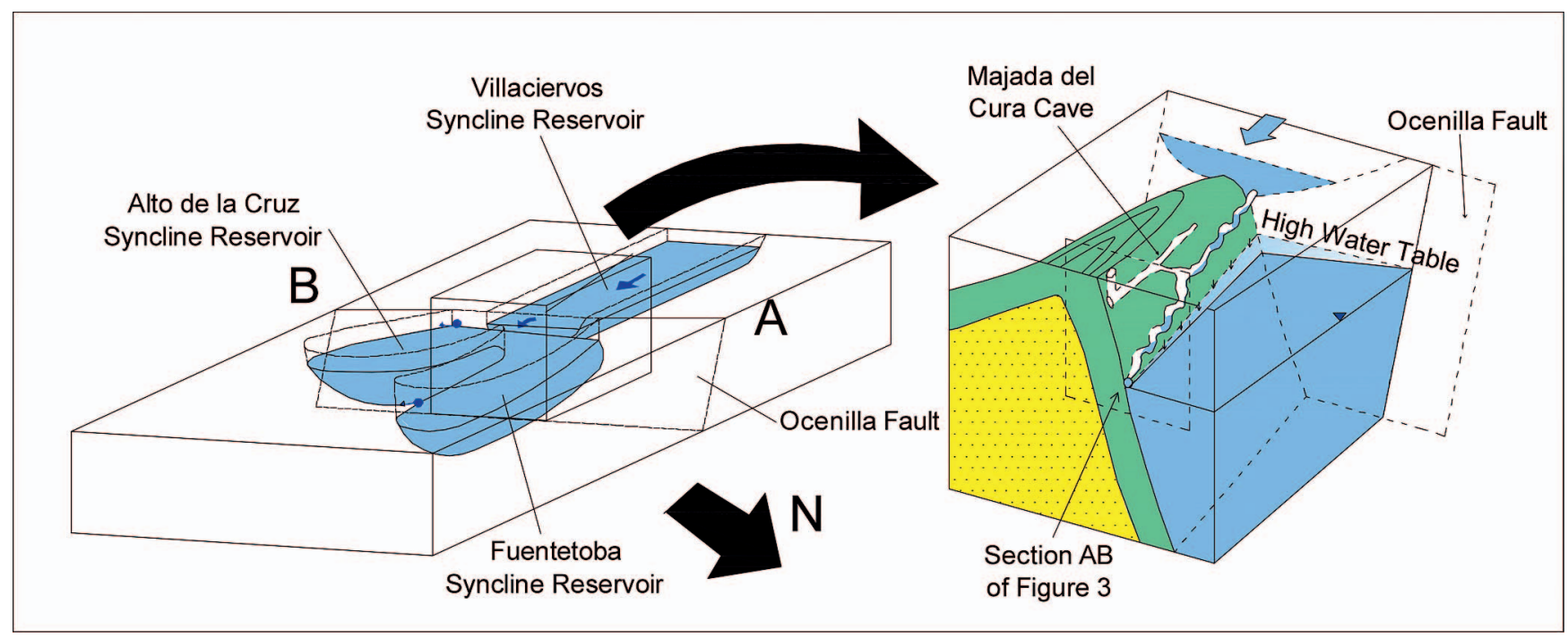

Figure 4. A conceptual three-dimensional model showing water flow in the three syncline reservoirs and the detailed geological location of Majada del Cura subterranean river. 


\section{Topography, Geology, and Groundwater Flow}

The aquifer feeding Fuentetoba Spring extends over an area of $26 \mathrm{~km}^{2}$. Its geometry combines a syncline on the western side of the Ocenilla Fault and the succession of a synclineanticline-syncline on the eastern side of this fault (Figs. 1b, 1c, and 4). The fold geometry is very well defined and placed the aquifer reservoirs mainly in the three hydraulically connected synclines. Together, they have a total groundwater storage capacity of between $5 \times 10^{6} \mathrm{~m}^{3}$ and $7 \times 10^{6} \mathrm{~m}^{3}$. The last syncline, called Pico Frentes, before arriving at Fuentetoba, holds between $2.76 \times 10^{6} \mathrm{~m}^{3}$ and $3.68 \times 10^{6} \mathrm{~m}^{3}$ of permanent reserves (the permanent water in Figure 2) that accounts for more than $50 \%$ of the whole aquifer (Rosas et al., 2016).

This calcareous unconfined aquifer is elevated in the manner of a meseta, and its edges are very precise, since all its edges outcrop on the slopes of the fairly impermeable Cenomanian-Turonian marls that form the base of the aquifer. The Fuentetoba Springs emerge where the impermeable marls occur at lower elevation $(1,140 \mathrm{~m})$ and at the source of the river Mazos $(1,150 \mathrm{~m})$. Recharge to this unconfined aquifer and peneplain is autogenic and diffuse. The recharge area of the Villaciervos syncline is around $20 \mathrm{~km}^{2}$, the Fuentetoba syncline covers $4.75 \mathrm{~km}^{2}$, and the syncline of Alto de la Cruz covers $4.25 \mathrm{~km}^{2}$.

Groundwater flows along the base of the synclines towards the Fuentetoba Springs $\left(210 \mathrm{~L} \mathrm{~s}^{-1}\right)$ and source of the river Mazos $\left(50 \mathrm{~L} \mathrm{~s}^{-1}\right)$. This river has a highly variable regime and low inertia, with several small discharges arising under highwater conditions. Thanks to the field data (Rosas, 2013) and hydrograph simulations of these springs using a mathematical rainfall-runoff model (Rosas et al., 2016) the mean waterbalance was calculated in detail for a 20 -year time series, as follows: rainfall $16.86 \times 10^{6} \mathrm{~m}^{3}(100 \%)$, natural recharge $8.35 \times 10^{6} \mathrm{~m}^{3}(49.53 \%)$, EVT $8.50 \times 10^{6} \mathrm{~m}^{3}(50.41 \%)$, groundwater pumping $0.01 \times 10^{6} \mathrm{~m}^{3}(0.06 \%)$, surface runoff 0 $\mathrm{m}^{3}$, and groundwater transfers to other aquifers $0 \mathrm{~m}^{3}$.

The structure of the aquifer takes the form of a syncline in the west whose axis dips towards the east. This conditions the convergence of flows and the accumulation of water at its heart, directing groundwater flow towards the east. An appreciable portion of the limb of this syncline lies outside the saturated zone (Figs. $1 \mathrm{~b}$ and $1 \mathrm{c}$ and 4 ), but water that infiltrates during recharge is efficiently returned to its core. Part of the groundwater is stored in the syncline of Alto de la Cruz, as has been demonstrated by prolonged tracer tests (Rosas et al., 2016), while water infiltrating into the catchment itself also collects in this syncline. However, the majority of flow is towards the Fuentetoba syncline, once it has passed the Ocenilla Fault. In this case, it undoubtedly passes through a number of galleries, including the Cave of Majada del Cura, which closely follows the contact with the limestone-marl beds as far as Fuentetoba Spring (Figs. 1c and 1d). Water stored in the Alto de la Cruz syncline is also directed toward Fuentetoba, except on the threshold of the anticline axis that separates these folds. Only the southern part of the syncline must feed the spring that is the source of the river Mazos (Fig. 4).

The situation is summarized in Figure 1 and Figure 4, showing the three hydraulically-connected synclines that act as groundwater reservoirs. The largest in size and the one with the largest recharge area is in the west, though it has relatively smaller storage capacity because it lies away from the discharge points and so its level fluctuates more. In contrast, the two smaller synclines to the east have thicker saturated zones and less variable levels, since they are situated close to the system's outlets.

\section{Caves, Submerged Conduits, and Subterranean RIVERS}

A number of smaller caves have been recognized in the karst system, including both potholes and caves, but two important ones will provide information about the epiphreatic and phreatic zones of the karst. One of the caves, Majada del Cura, is oriented east-west, and at $3 \mathrm{~km}$ it is relatively long and its lower galleries are active. The present-day vadose circulation is in the form of an underground river. In the stretch that clearly flows towards its emergence at Fuentetoba, the river forms a series of waterfalls and rapids interrupting longer sections of mostly free flow, though with a number of local siphons. Seven siphons have been identified in the explored galleries under low-water conditions but there may be other sections that also siphon during high-water periods (Figs. 1d and 2). The river is the main collector of other subterranean inflows into the karst massif. The water flows along the contact between the steeply inclined limestone and marly-limestone beds at the edge of the southern limb of the Pico Frentes syncline (Fig. 4). This gallery lies near the top of the phreatic zone, where speleogenesis is maximized. Its existence provides a natural drain and impedes any rise in water level after significant recharge events.

The other collector is a submerged cave, a pressure conduit associated with the outflow channel that drains the flow through Fuentetoba Spring. The cave is oriented N-S, is $350 \mathrm{~m}$ long, and descends through the unsaturated zone of the syncline aquifer to $45 \mathrm{~m}$ below the level of this spring (Fig. 3). A characteristic of the large springs of the Upper Cretaceous aquifers in this zone is the presence of phreatic conduits associated with them; the spring at Fuentona de Muriel emerges from a conduit that is more than $110 \mathrm{~m}$ deep and 400 $\mathrm{m}$ long (Sanz Pérez and Medina Ferrer, 1987), the spring at La Galiana flows from a conduit with some $400 \mathrm{~m}$ exploredlength (Segovia et al, 2011), and the Fuente Azul de San Pedro de Arlanza in Burgos emerges from a vertical phreatic conduit more than $100 \mathrm{~m}$ deep.

\section{RESULTS}

\section{Hydrology of the Majada del Cura Cave}

Over four years of exploration (2011-2015), a variety of observations have been made that are of hydrological interest. 
In very rainy spells, normally dry siphons in the intermediate galleries are flooded, temporarily impeding access to the deeper, dry galleries that lead to the underground river. The water filters slowly through the base of these flooded chambers and, after a few weeks, they dry out, restoring access to the cave network. The underground flow inside the cave is torrential, and the course includes rapids and waterfalls with siphons and lagoons in between. It drops some $70 \mathrm{~m}$ over a reach of $700 \mathrm{~m}$ towards the lowest point in the eastern end of the cave, a mere 5 or $10 \mathrm{~m}$ above the level of Fuentetoba Spring, even though this point is still some $2.5 \mathrm{~km}$ away from the spring (Fig. 4).

The underground flow has been point-gauged under various conditions, and the flow has varied from a few liters per second up to $500 \mathrm{~L} \mathrm{~s}^{-1}$, although the highest floodwaters have not been recorded. The overall perception gained over the years is that the flow through this cave forms an appreciable proportion of that emerging through Fuentetoba Spring. However, we cannot dismiss the possibility that other secondary supply conduits exist. Nevertheless, during a tracer test inside the cave under low-water conditions (and on other occasions as well), it was observed that the flow through the cave, at the time less than $10 \mathrm{~L} \mathrm{~s}^{-1}$, was greater than what was emerging at the spring.

Under moderate and high water conditions, the level is seen to rise up to the roof of the galleries and a number of siphons become flooded, so impeding conventional explorations. Moreover, some of the intermediate and upper siphons are flooded. Smooth cave walls with erosion scallops are common, typical of phreatic conduits. In the intermediate stretches of the gallery, there are marks on the walls in some of the chambers that indicate the height that some of the lakes can reach, which is $3 \mathrm{~m}$ above the watercourse in some instances. At certain points there are recent terraces of rounded $2 \mathrm{~cm}$ gravel $1 \mathrm{~m}$ above the present-day course of the underground river, while elsewhere there are flat deposits of sand, with current ripples above pebbles. We have occasionally seen them half a meter below the water surface. There are also potholes or marmites around some subcurrent rimstone dams or gours that are filled with the same kind of pebbles as on the terraces. Some are found some $2.5 \mathrm{~m}$ above the actual vadose channel and are generated by flood waves whose mechanical erosive action (corrasion) has been recorded in the breaks of slope in the watercourse at these calcite paleogours due to their relative softness. These geological formations have been preserved unaltered by the ordinary floods of these years when explorations were made, and they provide proof of violent and extraordinary floods in the past. Given the crosssection and slope of the river bed, such floods, which are still possible today, could have easily exceeded $3,000 \mathrm{~L} \mathrm{~s}^{-1}$.

Once the rain stops, the flow of the underground river rapidly diminishes, and the water level in the lagoons and siphons falls very quickly. During speleological explorations, the water level in this cave is notorious for falling several centimeters or even decimeters from one day to the next, though only rarely is there no flowing water. It has been observed that where the river is above the phreatic level, there is loss due to filtration through the floor that is more significant the higher the gallery lies.

As can be seen from Figure 2, the closest stretch of the explorable underground river to Fuentetoba Spring lies $2.5 \mathrm{~km}$ away in a straight line. Its galleries are a series of more or less open U-shaped siphons, which increase in number in the direction of flow and obstruct conventional exploration. Thus it appears that this is the overall trend until they emerge. This is not surprising, since, as mentioned above, there is another submerged conduit that feeds the spring, which almost certainly represents the final stretch of the hypogean river. Observations made during periods of drought show that the water in the siphons closest to Fuentetoba Spring is practically stagnant and the phreatic level is barely 5 to $10 \mathrm{~m}$ above the level of the spring, despite being so far away, with a calculated hydraulic gradient of $0.1 \%$ to $0.3 \%$, which is insufficient to allow a rapid flow of the groundwater.

\section{The Conduit of Fuentetoba Spring}

Fuentetoba Spring (elevation 1,140 m) emerges from a natural flooded gallery. The cave diving explorations were done during the long summer period of low water, when the rising current in the gallery was practically imperceptible. Under these conditions, the divers could proceed without danger. The level of the upper part remained constant at $2 \mathrm{~m}$ above the external spring. However, during the spring floods, the upper part of the conduit became inaccessible for conventional speleological explorations.

The conduit that leads to the spring has been explored for a distance of $350 \mathrm{~m}$, with a maximum elevation of $45 \mathrm{~m}$, above the spring, at an elevation of $1,095 \mathrm{~m}$. Over $350 \mathrm{~m}$ it rises almost vertically, up to zero level (Fig. 3). This rising exit conduit is tubular, which is very typical of deep phreatic circulation in the saturated zone of typical karstic aquifers. It is a single conduit with a quasi-cylindrical cross section extraordinarily constant in form. Its diameter is $2 \mathrm{~m}$ and it dips $20^{\circ}$ towards the north. The conduit penetrates quite far, reaching half the depth of the saturated zone at the heart of this small syncline, and thus, it allows efficient drainage of this part of the aquifer. Figure 3 shows the profile of this conduit within the Fuentetoba Syncline.

This cavity reflects the stratification. In the beginning, it would have been established in a particular bank of thick, homogeneous limestone that lies above one of the first marly intercalations that form the impermeable base of the aquifer. It roughly follows the dip direction of the beds, although its inclination is less than the dip of the strata. The conduit developed within this calcareous layer, almost invariably towards the center of the syncline, along a length of $350 \mathrm{~m}$. The end of the gallery is a single tube, whose vertical termination reaches as far as the water level, where it opens out into a chamber.

Throughout the shallower part of the conduit (Fig. 3) and under drought conditions when Fuentetoba Spring is dis-

Journal of Cave and Karst Studies, December 2016 • 189 
charging around 10 to $50 \mathrm{~L} \mathrm{~s}^{-1}$, the water level lies some $2 \mathrm{~m}$ above the spring. This is because the water escapes sideways through a crevice, discharges into an underground chamber, and emerges between the blocks and debris on the slopes of the Sierra de Pico Frentes (Fig. 3). However, the dry conduit persists for a few meters more until it opens onto the hillside. This outlet, situated $5 \mathrm{~m}$ above the spring and $2 \mathrm{~m}$ above the ponding (low-water) level of the conduit, contains water during very large floods (between $1,500 \mathrm{~L} \mathrm{~s}^{-1}$ and 2,000 L $\mathrm{s}^{-1}$ ), acting as an overflow route and disgorging a flow of up to $100 \mathrm{~L} \mathrm{~s}^{-1}$. Under such severe flood conditions, another outflow also comes into play. This lies below the overflow passage and communicates with the chamber referred to above (Fig. 3). It is funnel-shaped, and so water spurts out under pressure. Sediment on the bed of this spring is made up solely of limestone cobbles between 1 and $35 \mathrm{~cm}$ diameter. The pebbles are extraordinarily well rounded and polished. As the spring flow diminishes, the water level in the conduit and spring falls rapidly by several decimetres a day in line with the very fast emptying regime of this resurgence.

The main conduit contains no sediment deposits, except in its lower part where there are a few rounded pebbles. The walls of the tube have been subject to corrosion and have been sculpted all over with dissolution scallops, ranging from centimeters to decimeters in size (mean $20 \mathrm{~cm}$ ). This has produced smooth surfaces that have got an undulating micromorphology. The fact that the gallery contains no fillings indicates an active high-velocity circulation dominated by corrosion, in which sedimentation of sand and clays is impeded.

\section{Fuentetoba Spring Discharge Hydrograph}

In our case study, we assumed that the whole flow draining through the karst system was monitored over two hydrological years (2010-2011 and 2011-2012), though there may have been additional, diffuse subterranean outflows through fractures penetrating the marly base of the aquifer and transferring water to the sands of the Utrillas Facies and perhaps also small filtrations through the tuffs around the springs.

Over the two-year study period, a wide variety of hydrological situations occurred, ranging from prolonged drought to intense rainfall, which enabled diverse characteristics of this drainage to be analyzed. During the hydrological year 2010-2011, mean flow at this spring was around $200 \mathrm{~L}$ $\mathrm{s}^{-1}$, falling to $8 \mathrm{~L} \mathrm{~s}^{-1}$ during the dry season and rising to as much as $3,400 \mathrm{~L} \mathrm{~s}^{-1}$ after flood events. Thus, the spring's flow is highly irregular, is sensitive to the dry season, and has a relatively rapid response in one or two days to rainfall and snowmelt (Fig. 5). The sharp hydrograph peaks also indicate major development of karstic conduits, where conduit permeability may be predominant (Bonacci and Zivaljevic, 1993; Bonacci, 1993; Worthington, 1999).

After any dry period, short or long, we have observed that there is a delay of one or two days before the spring reacts to normal rainy periods. This lag is interpreted to reflect the time for the bulk of the wave in the vadose zone to arrive from the two synclines of Villaciervos and Alto de la Cruz. The rapid pressure pulses through the karstic conduits in the saturated zone are hardly noticeable in the ascending limb of the hydrograph peaks. However, these pressure pulses are prominently manifest in the siphoning behavior of the spring, as is observed from the operation of the underwater gallery and the overflow passage associated with it.

The hydrograph of the spring manifests two kinds of emptying. In the first kind, the bulk of the groundwater empties very quickly under a predominantly turbulent regime, as indicated by the slope of the recession curve on semilogarithmic paper $\left(\alpha_{1}=0.18 \mathrm{~d}^{-1}\right)$. The mean flow at the beginning of the recession curve is $800 \mathrm{~L} \mathrm{~s}^{-1}\left(70 \times 10^{3} \mathrm{~m}^{3}\right.$ $\mathrm{d}^{-1}$ ). The second kind of emptying is the curve that occurs with very low flows, normally below $25 \mathrm{~L} \mathrm{~s}^{-1}$. It represents the emptying through both large and small conduits, as we were able to observe in the cave-dive surveys. The slope of the hydrograph is very shallow $\left(\alpha_{2}=0.008 \mathrm{~d}^{-1}\right)$, which means that the spring does not stop flowing. The mean flow at the start of the recession curve with $\alpha_{2}$ is $23 \mathrm{~L} \mathrm{~s}^{-1}\left(2,000 \mathrm{~m}^{3} \mathrm{~d}^{-1}\right)$,

Several composite hydrograph recessions have been observed. Following the usual recession curve analysis (Ford and Williams, 2007), the expression obtained for this case is

$$
Q_{t}=Q_{01} e^{-\alpha_{1} t}+Q_{02} e^{-\alpha_{2} t}=70 \times 10^{3} e^{-0.18 t}+2,000 e^{-0.008 t}
$$

where flow $Q$ is expressed in $\mathrm{m}^{3} /$ day and time $t$ in days.

$$
\begin{aligned}
& V_{1}=\frac{Q_{01}}{\alpha_{1}}=\frac{70 \times 10^{3}}{0.18}=4.0 \times 10^{5} \mathrm{~m}^{3} \\
& V_{1}=\frac{Q_{02}}{\alpha_{2}}=\frac{2,000}{0.008}=3.0 \times 10^{5} \mathrm{~m}^{3} \\
& V=V_{1}+V_{2}=7.0 \times 10^{5} \mathrm{~m}^{3}
\end{aligned}
$$

\section{Discharge Hydrograph of the Siphoning FuENTETOBA SPRING}

Figure 5 shows the gauged and simulated hydrograph (Rosas et al., 2016) of the Fuentetoba spring for the hydrological years 2010-2011 and 2011-2012, the latter obtained using the unicellular mathematical model CREC (Guilbot, 1975). It indicates that when precipitation and natural recharge are small, the gauged outflow at the spring is less than simulated. However, the gauged outflow is lower than the simulation when precipitation is greater. These are relatively small, but clearly visible differences as seen from the $\mathrm{B}(-)$ and $\mathrm{D}(-)$ expanded periods in Figure 5. One must take into account that CREC is a model of regional implementation based on water balance on soil and blackbox with reservoirs. The model does not include various things observed in other karst systems, such as constriction 


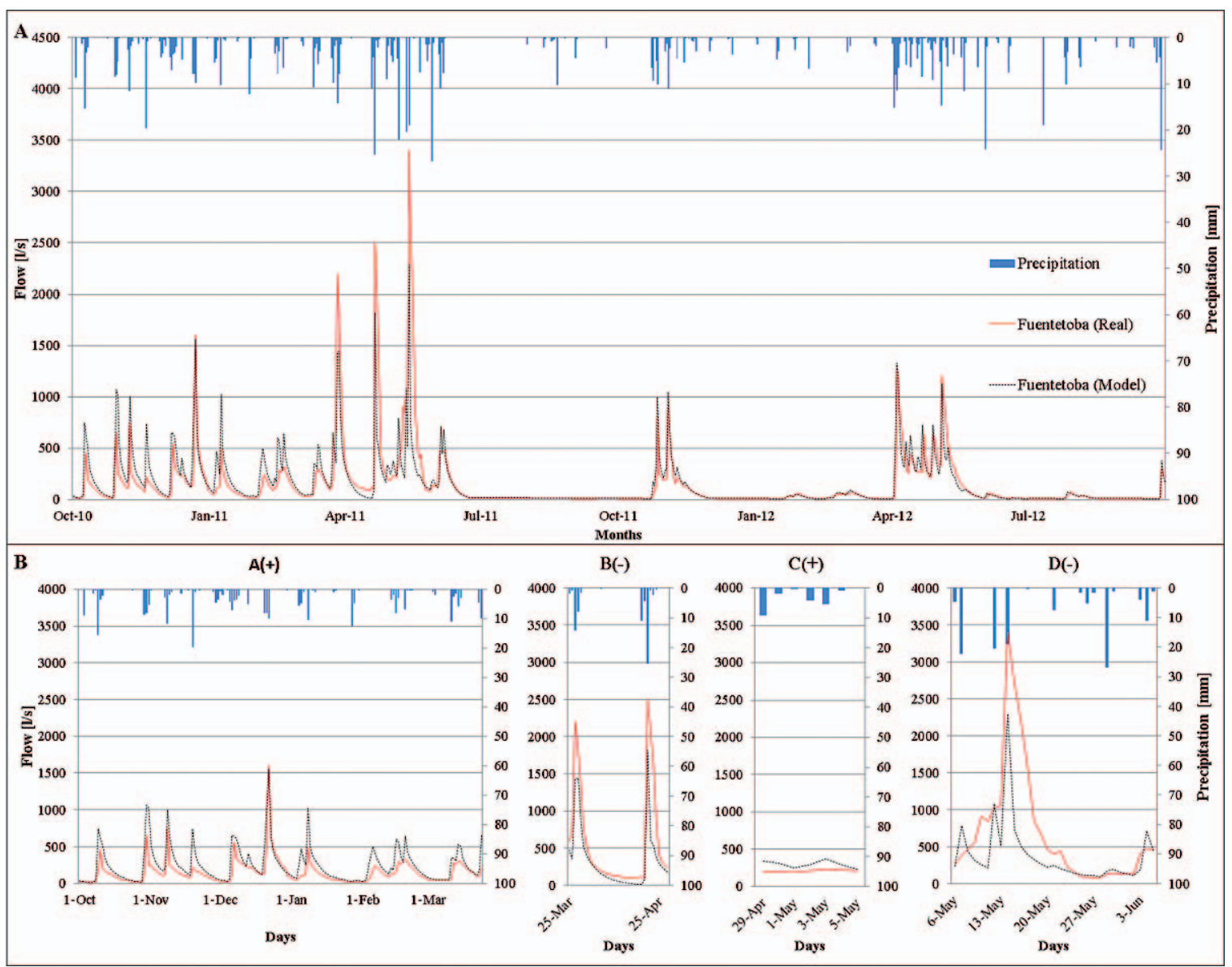

Figure 5. A. Actual and simulated hydrographs of the Fuentetoba Spring for 2012-2013 with precipitation record for comparison. The periods of water storage and water deficit are expanded. They are interpreted as being due to impulsion under pressure and siphoning. B. Showing the fact that there is an ebb-and-flow phenomena originated some distance away.

phenomena, plugs of sediment in the conduits, siphoning, or any other mechanism involving long response times to recharge.

It has also been observed that during precipitation events when there is intense and significant recharge, the volume of water issuing from the spring is greater than the amount predicted by hydrograph modelling; see the periods highlighted (-) in Figure 5. Between March 25, 2011 and April 18, 2011 , the actual spring flow was $0.33 \times 10^{6} \mathrm{~m}^{3}$ more than calculated by the model. Between the May 9, 2011 and May 20,2011 , the measured discharge was $0.68 \times 10^{6} \mathrm{~m}^{3}$ more, and between May 30, 2011 and June 7, 2011 the gauged flow was $0.36 \times 10^{6} \mathrm{~m}^{3}$ higher. These periods of anomalous flow are short, one to two weeks at most, and this phenomenon occurred three times in 2011. Given the strong karstification of the aquifer and its very low inertia, it would be reasonable to think that the same volume of water recharged would be expelled after a short time, but not a smaller or larger amount.

A relatively important issue in applying the mathematical model was the impossibility of simulating some of the peaks under high and low flow conditions in detail. For the purposes of the hydraulic balance, this does not matter much. However, we believe that the anomalies may be attributable to the peculiarity of the hydrogeological karst and that the model failed because it is designed to simulate behavior of karstic aquifers.

This invites the question whether the aquifer has a larger catchment than inferred. However, this is not the case, since its recharge area is very well defined (Rosas, 2013). It cannot be fully explained by the cumulative effect of a snowmelt, shifted in time, because precipitation falling as snow is not considerable and this phenomenon is repeated consistently. According to the mathematical model, while during two events there was no snow, much of the reserves (approximately $1.0 \times 10^{6} \mathrm{~m}^{3}$ ) were produced corresponding with several snowfalls (December 2009 and March 2010).

Our explanation for both phenomena together is that part of the water coming from rainfall during dry periods is stored in the aquifer and that this same water emerges from the aquifer during wet periods. This is suggested by some of the direct observations made inside the caves (see above) of galleries in the unsaturated zone that temporarily retain the water in 
Table 1. Injections conditions for the uranine tracer test at Cave of Majada del Cura, 2,500 m from Fuentetoba.

\begin{tabular}{|c|c|c|c|c|c|}
\hline \multirow[b]{2}{*}{ Injection No. } & \multicolumn{2}{|c|}{ Tracer Injection Period } & \multirow[b]{2}{*}{ Tracer } & \multirow[b]{2}{*}{ Tracer Mass, $\mathrm{g}$} & \multirow[b]{2}{*}{ Stream Flow, $\mathrm{L} \mathrm{s}^{-1}$} \\
\hline & Date & Time, h & & & \\
\hline \multirow[t]{2}{*}{1} & July 14, 2012 & 1400 & uranine & 35 & 3.12 \\
\hline & & & $\mathrm{NaCl}$ & 20,000 & \\
\hline 2 & Oct. 16, 2012 & 1900 & uranine & 35 & 5 \\
\hline 3 & May 17, 2012 & 1800 & uranine & 100 & 4 \\
\hline
\end{tabular}

hanging lagoons and the presence of a reservoir of quasistagnant groundwater in low-water periods in the last of the three synclines at Fuentetoba. Moreover, we have confirmed the establishment of siphons with associated air chambers and lagoons upstream of the spring, which would serve as reservoirs prone to siphoning.

We observed that this groundwater reservoir in the Fuentetoba Syncline is rapidly increased in high-water periods due to the inflow from the underground river in Majada del Cura cave and other unknown sources. It provokes an excessive rise in the phreatic level and in the hydraulic head in the submerged galleries and so increases the water velocity and volume issuing from the spring. We also confirmed this hydrology using tracer tests.

\section{Discussion of the TRACER Results}

Three chemical tracer tests were done during 2012 and 2013 (Table 1) to verify the connection between the discharge points and the existing springs, as well as to measure the groundwater flow velocities. The tracer used was uranine, classically employed in karst environments (Käss, 1998), as well as $\mathrm{NaCl}$ once. The quantities of tracer used were $35 \mathrm{~g}, 35$ $\mathrm{g}$, and $100 \mathrm{~g}$ of uranine each for the three tracer tests, and 20 $\mathrm{kg}$ of $\mathrm{NaCl}$ for the first tracer test. Given that there are no permanent surface watercourses and only rarely ephemeral ones, the chosen point of injection was the underground river in the Majada del Cura Cave.

The Fuentetoba Spring was monitored by taking two samples per day. Water samples were stored in $100 \mathrm{ml}$ plastic bottles and refrigerated in darkness to minimize any microbial or photo degradation. Spectrometry was done very shortly after sampling. To determine the true uranine concentration in each test, all samples were analyzed and compared with a spring water sample taken before the survey, and care was taken to separate the various tests sufficiently over time to avoid interference from earlier tests.

Three tests were done in the underground river in the cave at Majada del Cura during low-water periods, although later, there were sudden changes due to rainfall. The tests were repeated several times because at the time we did not suspect any siphoning behavior and the monitoring time was set too short and no tracer was detected at the outlet. It was expected that the tracer would reappear rapidly, corresponding to the velocity of the underground river under turbulent regime and, in any case, with the same velocity as measured in the similar aquifer of Fuentona de Muriel, where flow velocity is $500 \mathrm{~m} /$ day under low-water conditions and 3,000 m/day under highwater conditions (Pérez and Sanz, 2011). However, this was not the case.

In terms of the three tests conducted in the Majada del Cura cave, which lies some 2,500 $\mathrm{m}$ from the Fuentetoba Spring, we made the following interpretation. The first test was done during the dry season when there was very little flow in the underground river. The tracer water was held back in the galleries of the syncline or travelled very slowly and almost certainly emerged after a rainy period. During the second test, the tracer was again held back and was remobilized by a new flood flowing through the system several days after the injection. The same thing occurred during the third test following a rainy spell after the test. The tracer appeared later. We assume the recharge into the aquifer from this rain event carried the remaining diluted tracer along the hypogean river and was held up in the standing-water zones (Fig. 6).

There are no outflows between the injection point into the subterranean river and Fuentetoba Spring. The recovery of the tracer was high $(85 \%)$ but incomplete; this could well have been due to measurement errors or small, unmonitored and unquantifiable seepages in the vicinity of the spring.

Overall, the tracer tests demonstrated that in the last of the three synclines, before issuing from Fuentetoba Spring, part of the groundwater flow became ponded in siphons and lagoons due to the low-water conditions. It emerged later when there was a significant impulsion of recharge water. The tracer tests also delimited this (siphoning) phenomenon to the $3,000 \mathrm{~m}$ stretch between the end of the explored part of the cave and the spring, through the whole of the small, elongated Fuentetoba syncline. However, we cannot discount that there may be other siphons operating upstream of the cave, as stated above. At least in this segment of the aquifer, it does not make sense to speak of groundwater velocity, because this velocity depends on when the recharge event occurs, a characteristic observed in other karstic aquifers (Field and Pinsky, 2000; Goldscheider N., 2005; Goldscheider N., 2008).

\section{DisCUSSION}

The long response times to recharge into the Fuentetoba karst seen in the hydrograph of the spring are a result of regional effects that have been simulated in a reasonably satisfactory way. The prolonged tracer tests that were done in 

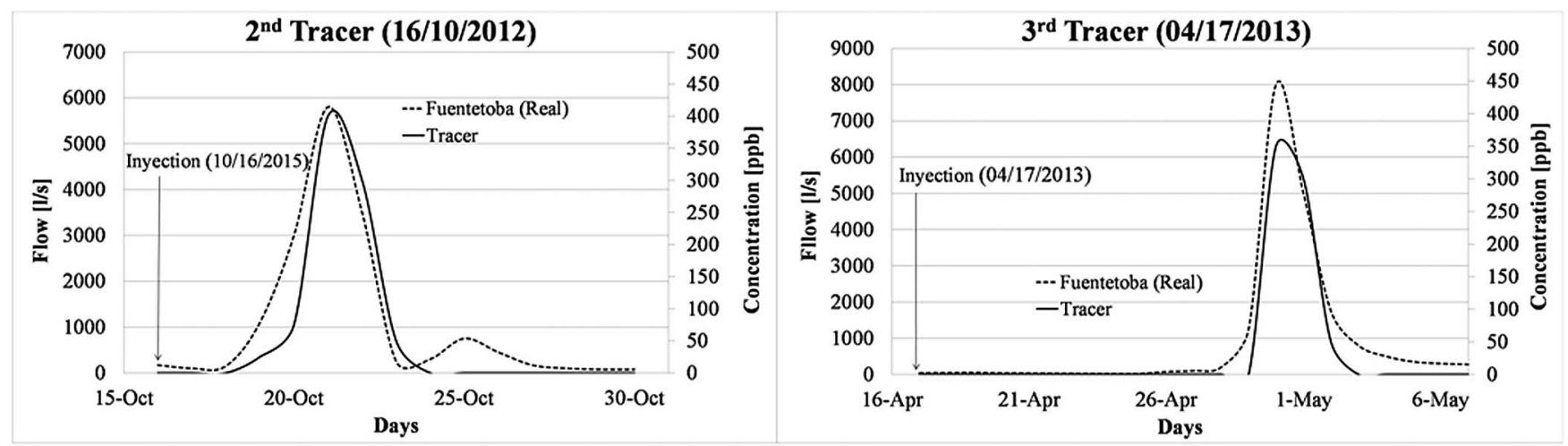

Figure 6. Curves of concentration against time for the tracer tests undertaken in the Fuentetoba Syncline, between the underground river and the spring.

the Villaciervos syncline that demonstrate the connection with Fuentetoba Spring have given the best overall representation of the drainage of this system (Rosas et al., 2016).

Nevertheless, some responses with a very long time-lag that manifest under high-water conditions are seen in a qualitative way in the hydrograph, but they could not be quantified using numerical modelling. The mechanism governing this response must be a non-Darcian physical model under a turbulent flow regime that occurs following rainy periods in the final stretch of the flowpath within this karst system, that is to say, in the Fuentetoba syncline. Its location has been narrowed down to this final stretch by the results of the short-distance tracer tests that were done in the conduit of the subterranean river in the extreme west of this syncline. It is not only the tracer tests that verify the phenomenon, but also the fact that if these ebb-and-flow phenomena (Figure 5.B) originated some distance away, their effects would be diminished by the time they reached the spring.

The characteristics of the system through the conduits were made evident by the ponding of the tracer water for days, weeks, and months and then a rapid emptying during periods of flood. Nevertheless, the spring continued to issue a smaller flow during the recession phase, which must be due to matrix flow through the syncline along hydraulic gradients that are distinct from those of the conduit flow.

Figure 7 explains the model proposed for the drainage of this karstic system. It is a model of three successive reservoirs that exist as hydraulically connected synclines by means of a subterranean river. It has to assume that the synclines accommodate different types of flow (matrix, fracture, and conduit flow), as if there were other virtual reservoirs with high and low permeability. The reality is undoubtedly more complex. For example, during the speleological explorations, there was evidence of water storage in the unsaturated zone conduits as small hanging pools that are seasonal by nature and that empty quite slowly. This is what happens in the temporal lake in Cueva de Villaciervos in the epikarst zone, where the bed of the lake is clayey, as indicated by Sanz and López (2000).

The general outline for this network indicates that an active channel hydraulically connects the various parts of the aquifer, behaving under moderate and high-water conditions as a drain from the synclines of Villaciervos and Alto de la Cruz, towards the Fuentetoba syncline. In detail, it can be seen how the preferential flowpaths of the hypogean circulation have become well established along a particular layer of limestone that abuts the sharp crest of the Fuentetoba anticline (Figures 3 and 4). These limestone layers, running east-west and dipping between $45^{\circ}$ and $65^{\circ}$ on its northern limb, determine that the conduit network is very rectilinear and follows the direction of the strata (Fig. 3). The limestone is exactly the same as the one at Fuentetoba Spring. It is very probable that the network of explored galleries continues in a straight line eastward towards this spring, which is the likely final destination of the hypogean river, having flowed through a succession of numerous siphons (Figs. 2 and 7)

Figure 2 explains how this phenomenon could occur. It can be observed that, although the recharge of quite rainy spells is uniformly spread out, $50 \%$ of the recharge surface of the entire aquifer lies over the syncline farthest from Villaciervos. In this section, there is an inordinate elevation of the phreatic level due to the concentration of recharge water coming from the limbs of the fold lying above the unsaturated zone. Under very high water periods, the phreatic level overtops the topography of a valley and creates the ephemeral spring of Las Fuentes (Villaciervos Spring in Fig. 1). However, the level in the Fuentetoba syncline does not vary because of its proximity to the outlet and the lack of a significant hydraulic gradient, which means that the velocity in this section of the aquifer is low; under low-water conditions, it can be practically zero.

We have not yet observed pressure propagation from these pulses of local recharge, since the hydraulic connection between these synclines is not very large (as is clear from Fig. 1b) because it is impeded by the throw of the Ocenilla Fault. The existence of the underground river in the cave indicates

Journal of Cave and Karst Studies, December 2016 193 


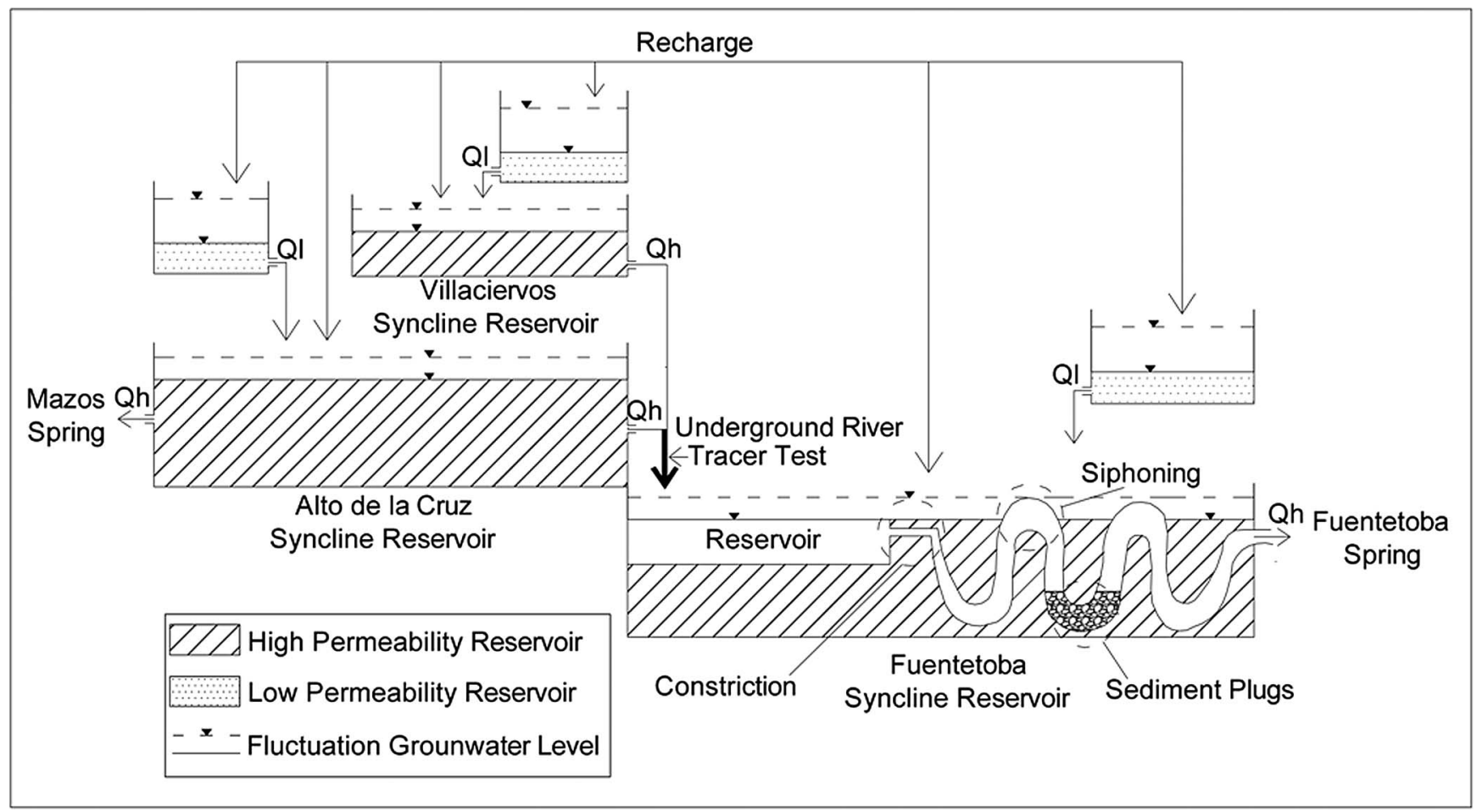

Figure 7. Simplified schematic model in which the three reservoirs in the three synclines in the karst system of Fuentetoba Spring are shown. It is assumed that the flow in each one is distributed in two deposits of high and low permeability. In the last reservoir (Syncline Fuentetoba) there are three potential hypothesis of the delayed flow: siphoning, sediment plugs, and passage constrictions, or a combination of those. Qh: Outflow coming from the high permeability reservoir; QI: Outflow coming from the low permeability reservoir. The location of the tracer injection in the underground river is shown.

that there is basically a free-flowing, fluvial regime as far as the start of the Fuentetoba Syncline.

It has been observed how this current increases rapidly a day or two after heavy rain. This hypogean network behaves in a similar fashion to a dendritic drainage network of a torrential river, capturing the recharged water into the synclines farther upstream. The flood wave coming from the syncline farthest from Villaciervos passes through the Ocenilla Fault and is redirected through the cave.

During periods of recession, the water flowing along the subterranean river is $4 \mathrm{~L} \mathrm{~s}^{-1}$ more than what emerges at Fuentetoba Spring. Our interpretation is that on these occasions the water is being impounded or stored before it reaches the spring.

From the end of the explored section of this subterranean river, a syncline extends over the $3 \mathrm{~km}$ distance to Fuentetoba. The impounded groundwater is calculated to be between 2.76 $\times 10^{6} \mathrm{~m}^{3}$ and $3.68 \times 10^{6} \mathrm{~m}^{3}$ (Rosas et al., 2016), has practically no gradient, and is stagnant. Here, there must be numerous submerged conduits and siphons where the movement and response to floods must be activated to a large extent through pressure propagation. When the bulk of the kinematic flood of the subterranean stream enters this area, which is as yet unexplored, it should produce an elevation of the water level in the siphons and intermediate lagoons, flooding them, especially the narrow passages. At this final area, there are various possible explanations for the anomalous behavior of the system's drainage and, in fact, a combination of these could be acting, since no one possibility contradicts any other.

Observations over the final accessible stretch of the conduit that leads to the spring confirm that there are no sediment plugs, nor even any bottom sediment, and it is not known for this spring to expel sediments or debris. Its waters are almost always very clear, at least over the four years of observations. Outside, there are neither terraces nor deposits that have been expelled by the spring, only calcareous tuffs. The transport of sediments by the subterranean river under normal flood conditions must be very small, as observed during the speleological surveys, since the current is not turbid, nor does it contain a significant sand load. It should be noted that the catchment of the subterranean river is autogenous and that there is no external sediment source. Nevertheless, there are occasional hanging banks of sand or rounded pebbles that have been deposited during exceptional floods, which testify to the presence of a sediment load that must be deposited in the lower parts of the conduits of the lowest syncline of Fuentetoba. There have been no direct observations of 
changes in water level in the final stretch of the underground torrent, nor marks or sediment terraces that would belie a sudden rise in level caused by a plug farther downstream. However, since the network of galleries that must exist between the explored part of the cave containing the underground river and the spring, nearly $3 \mathrm{~km}$ away, is unknown, we cannot reject the possibility that gravel or sand plugs are present at the base of other, unexplored siphons, which are not ejected by the spring but enter suspension and later settle out again.

Another possible explanation would be the existence of constrictions in the conduits, as actually happens in several siphons of this subterranean torrent, where the variations in water level in the associated reservoirs upstream can be as much as 2 or $3 \mathrm{~m}$ during high water periods. A similar thing could also occur farther downstream. However, there is no physical evidence of this happening, nor have we seen any large oscillations in water level in the final stretch of the underground torrent. Neither have we encountered sediments due to a decrease in flow upstream of the hypothetical constrictions. Nevertheless, to dismiss the constrictions hypothesis, the network of unexplored galleries needs to be better understood.

The $700 \mathrm{~m}$ or so of explored subterranean river contains seven small siphons, and the explored section of the submerged conduit just upstream of the spring contains the beginning of a large siphon. These observations suggest that the network of conduits in the intermediate section is likely linked by means of a series of siphons. If there were inverted siphons in the unexplored stretch, they could be primed by stream flow during periods of flood, producing suction of water from the lagoons and flooded galleries, so emptying a large volume of ponded water in a short time. This would mean that the flow discharged would be greater than the volume coming from the recharge wave. This could plausibly be the predominant mechanism, without needing to dismiss the other mechanisms described above.

Moreover, given the dimension of the outlet at Fuentetoba Spring, the outlet must be very sensitive to pressure variations, and an excess-pressure of a few centimeters at its base would be enough to provoke an upward flow as far as the overflow outlet. The known tube behind the spring is about $350 \mathrm{~m}$ long and reaches $42 \mathrm{~m}$ deep. It discharges about $50 \mathrm{~L} \mathrm{~s}^{-1}$ with an average hydraulic diameter of $1.6 \mathrm{~m}$. With greater discharges the flow becomes stronger.

The increases in water level due to the recharge from intense rainfall events or snow melt, means that there is an increase in hydraulic head between the lower and upper ends of the tube. This increases the flow and its velocity. We conclude that the system presents very large variations in both flow and pressure, and that small differences in pressure caused by the transmission of pressure waves due to recharge into the syncline are sufficient to mobilize the old, stagnant water held in the outlet-conduits of the spring.

According to Curl (1966) the mean paleovelocity can be calculated from the scallop length and the hydraulic diameter of the outflow conduit. For Fuentetoba Spring, this gives a result of 10 to $15 \mathrm{~cm} \mathrm{~s}^{-1}$, which is faster than the critical velocity for laminar flow in a cylindrical conduit $1.5 \mathrm{~m}$ in diameter and with a $15^{\circ}$ slope. In other words, the paleoregime of this conduit was turbulent, and its velocity would be approximately equivalent to a flow of between $800 \mathrm{~L} \mathrm{~s}^{-1}$ and $900 \mathrm{~L} \mathrm{~s}^{-1}$.

This expulsion of old stagnant water under pressure close to the outlet spring has been observed in many karstic systems (Yevjevich, 1981), but the siphoning phenomenon, the regular evacuation through an inverse U-shaped siphon, occurs only rarely, such as at the source of the river Mundo in Spain (Rodríguez-Estrella et al., 2002). This explains the surplus flows and the remobilization of semi-stagnant water which, in our case, was tinged with fluorescein from the tracer tests. The reservoirs emptied by the siphoning are refilled following nontorrential rain events, then they discharge again. A simple emptying calculation of an assumed 3,000 $\mathrm{m}$ long gallery with a $10 \mathrm{~m}^{2}$ cross-section, a similar continuation to the Cave of Majada del Cura, would involve $30,000 \mathrm{~m}^{3}$. The Fuentetoba siphon alone would give a volume of around $1,500 \mathrm{~m}^{3}$. It is easy to conjecture a network of conduits through the entire syncline that would explain the calculated volumes of between $0.33 \times 10^{6} \mathrm{~m}^{3}$ and $0.68 \times 10^{6} \mathrm{~m}^{3}$ issuing from the siphons in 2011.

\section{Conclusions}

The overall drainage of the karst in the Fuentetoba Spring system and the wide amplitude of the hydrograph following recharge are determined by regional effects and by the complex geology comprising three synclines that are hydraulically connected by means of a fault and a subterranean river. Certain responses with a very long time-lag manifest under high water conditions and suggest a system with a quite rare hydrological behavior.

To understand the karstic drainage system of Fuentetoba Spring better, we monitored the emerging flow. In the interior of a cave, we made direct observations by conventional caving and by cave diving of an important and representative part of the conduits in the karst.

The hydrograph of the spring has a very pronounced variability, with sharp peaks and rapid emptying. There is no inertia, and the spring does not maintain hydrodynamically significant volumes for any period of time. This is not only a consequence of the small recharge area of the aquifer, but also of the network of conduits that carry predominantly turbulent flow through a very well developed karst system.

The flow in the vadose zone is characterized by an underground river that is torrential in nature and consists of free-flowing sections over a series of rapids, waterfalls, and lakes, with intervening stretches of forced phreatic flow in sumps that are most significant in the epiphreatic zone. In the phreatic zone, forced deep conduction through large conduits seems to predominate. The outflow at the spring is through a 
large-diameter conduit with a high discharge capacity, and the flow quickly goes from laminar to turbulent regime and is very sensitive to changes in the groundwater head motivated by flood events. Erosion marks along this outflow tube and associated gravel deposits indicate high velocities and flows exceeding $1000 \mathrm{~L} \mathrm{~s}^{-1}$.

According to the hydrograph analysis and the tracer tests, part of the recharge water during dry periods is stored through the dry period in the last of the three synclines, where the subterranean stream ponds up. This water is later released during wet periods. The responses to these recharge events following low water periods could be governed in the final stretch by mechanisms of impulsion under pressure or by siphoning of the flood wave, since we assume that the siphon geometry continues through the unexplored part of the karst. However, other possible mechanisms cannot be rejected, such as constrictions and sediment plugs in the conduits.

\section{ACKNOWLEDGEMENTS}

We should like to thank Carlos Morón Egido, Carlos Morón Vicén, and Manuel Jiménez Sánchez from Terrasub and Deportes Espeleo for all their logistical support in exploring the caves of Majada del Cura and in reading the flow gauges installed at the springs. Also we appreciate and thank very much the detailed comments and suggestions of reviewers and editors who helped us to improve strongly the original manuscript.

\section{REFERENCES}

Atkinson, T.C., 1977, Diffuse flow and conduit flow in limestone terrain in the Mendip Hills, Somerset (Great Britain): Journal of Hydrology, v. 35, p. 93-110. doi:10.1016/0022-1694(77)90079-8.

Bakalowicz, M., 2005, Karst groundwater: a challenge for new resources. Hydrogeology Journal, v. 13, p. 148-160. doi:10.1007/ s10040-004-0402-9.

Benischke, R., Goldscheider, N., and Smart, C., 2007, Tracer techniques, in Goldscheider, N., and Drew, D., eds., Methods in Karst Hydrogeology: London, Taylor and Francis, International Association of Hydrogeologists, International Contributions to Hydrogeology 26, p. 140-170.

Bonacci, O., 1993, Karst spring hydrographs as indicators of karst aquifers: Hydrological Sciences Journal, v. 38, p. 51-62. doi:10.1080/ 02626669309492639.

Bonacci, O. and Živaljević, R., 1993, Hydrological explanation of the flow in karst: example of the Crnojevića spring: Journal of Hydrology, v. 146, p. 405-419. doi:10.1016/0022-1694(93)90287-J.

Curl, R.L., 1966, Scallops and flutes: Transactions of the Cave Research Group of Great Britain, v. 7, no. 2, p. 121-160.

Field, M.S., and Pinsky, P.F., 2000, A two-region non-equilibrium model for solute transport in solution conduits in karstic aquifers: Journal of Contaminant Hydrology, v. 44, no. 3-4, p. 329-351. doi:10.1016/ S0169-7722(00)00099-1.

Ford, D.C., and Williams, P., 2007, Karst Hydrogeology and Geomorphology: Chichester, UK, Wiley, $562 \mathrm{p}$.

Geyer, T., Birk, S., Licha, T., Liedl, R., and Sauter, M., 2007, Multitracer test approach to characterize reactive transport in karst aquifers: Groundwater, v. 45, no. 1, p. 36-45. doi:10.1111/j.1745-6584.2006.00261.x.

Geyer, T., Birk, S., Liedl, R., and Sauter, M., 2008, Quantification of temporal distribution of recharge in karst systems from spring hydrographs: Journal of Hydrology, v. 348, no. 3-4, p. 452-463. doi:10.1016/j.jhydrol.2007.10 015 .
Goldscheider, N., 2005, Fold structure and underground drainage pattern in the alpine karst system Hochifen-Gottesacker: Eclogae Geologicae Helvetiae, v. 98, no. 1, p. 1-17. doi:10.1007/s00015-005-1143-z.

Goldscheider, N., 2008, A new quantitative interpretation of the long-tail and plateau-like breakthrough curves from tracer test in the artesian karst aquifer of Stuttgart, Germany: Hydrogeology Journal, v. 16, no.7, p. 13111317. doi:10.1007/s10040-008-0307-0.

Goldscheider, N., and Andreo, B., 2007, The geological and geomorphological framework, in Goldscheider, N., and Drew, D., eds., Methods in Karst Hydrogeology: London, Taylor and Francis, International Association of Hydrogeologists, International Contributions to Hydrogeology 26, p. 9-23.

Goldscheider, N., Meiman, J., Pronk, M., and Smart, C., 2008, Tracer tests in karst hydrogeology and speleology: International Journal Speleology, v. 37, no. 1, p. 27-40. doi:10.5038/1827-806X.37.1.3.

Guilbot, A., 1975, Modélisation des ecoulements d'un aquifère karstique (liaisons pluie-débit). Application aux basins de Saugras et du Lez [Thése d'Université], Université des Sciences et Technologies de Lille (USTL), Montpellier, France, $110 \mathrm{p}$.

Halihan, T., and Wicks, C.M., 1998, Modeling of storm responses in conduit flow aquifers with reservoirs, Journal of Hydrology, v. 208, no. 1-2, p. 8291. doi:10.1016/S0022-1694(98)00149-8.

Halihan, T., Wicks, C.M., and Engeln, J.F., 1998, Physical response of a karst drainage basin to flood pulses: example of the Devil's Icebox cave system (Missouri, USA), Journal of Hydrology, v. 204, no. 1-4, p. 24-36. doi:10. 1016/S0022-1694(97)00104-2.

Instituto Geológico y Minero de España (IGME), 1980, Mapa Geológico de España 1:200.000, no. 31 .

Instituto Geológico y Minero de España (IGME), 1982, Mapa Geológico de España 1:50.000, no. 349 .

Karimi, H., and Ashjari, J., 2009, Periodic breakthrough curve of tracer dye in the Gelodarech Spring, Zagros, Iran: Cave and Karst Science, v. 36. no 1., p. 5-10.

Käss, W., 1998, Tracing Technique in Geohydrology: Rotterdam, Balkema, $582 \mathrm{p}$.

Mangin, A., 1974-75, Contribution à l'étude hydrodynamyque des aquifères karstiques: Thèse d'Etat, Annales de Spéléologie, v. 29, no. 3, p. 283-332; v. 29 , no. 4 , p. 495-601; v. 30, no. 1, p. 21-124.

Milanovic, S., 2007, Hydrogeological characteristics of some deep siphonal springs in Serbia and Montenegro karst: Environmental Geology, v. 51, p. 755-759. doi:10.1007/s00254-006-0391-1.

Navarro, D., 1991, Mapa Geológico de España. 1:50.000, no. 359, p. 14-23.

Pérez, J.J., and Sanz, E., 2011, Hydrodynamic characteristics and sustainable use of karst aquifer of high environmental value in the Cabrejas range (Soria, Spain): Environmental Earth Sciences, v 62, p. 467-479. doi:10. 1007/s12665-010-0540-4.

Perrin, J., and Luetscher, M., 2008, Inference of the structure of karst conduits using quantitative tracer tests and geological information: example of the Swiss Jura. Hydrogeology Journal, v. 16, no. 5, p. 951-967. doi:10.1007/ s10040-008-0281-6.

Rodríguez-Estrella, T., Ballesta, J.M., Melero, J.M., and Martinez, J.A., 2002, Contribución de las medidas de conductividad y $\mathrm{pH}$, en las aguas de la Cueva los Chorros del rio Mundo (Albacete), a la génesis del enigmático "reventón", in Carrasco, F., Duran, J.J., and Andreo, B. eds., Karst and Environment: Nerja-Malaga, Spain, Fundación Cueva de Nerja, p. 199 209

Rosas, P., 2013, Hidrogeología del acuífero kárstico de Pico Frentes (Cordillera Ibérica) [Ph.D. Dissertation]: Madrid, Universidad Politécnica de Madrid, $257 \mathrm{pp}$.

Rosas, P., Sanz, E., and Menéndez-Pidal, I., 2016, Hidrogeología del Karst de Pico Frentes (Cordillera Ibérica, España): Estudios Geológicos, v. 72, no. 1, article e047, 21 p. doi:10.3989/egeol.42132.375.

Sanz Pérez, E. and Medina Ferrer, J., 1987, Le siphon de La Fuentona de Muriel (Soria-Espagne). Karstología, no. 9, p. 27-30.

Sanz, E., and Lopez, J.J., 2000, Infiltration measured by the drip of stalactites: Groundwater, v. 38 , no. 2, p. 247-253. doi:10.1111/j.1745-6584.2000. tb00336.x.

Sanz Pérez, E., Pérez Santos, J.J., Menéndez-Pidal, I., Meneses Canalejo, J.M., and Molina Martín, C., 2012, Guía Geológica de la Sierra de Cabrejas y del Monumento Natural de la Fuentona: Diputación Provincial de Soria, $150 \mathrm{p}$.

Sara, M.N., 1977, Hydrology of Redwood Canyon, Tulare County, California [M.S. Thesis]: University of Southern California, 129 p.

Segovia Rosales, R., Sanz Pérez, E., and Menéndez-Pidal, I., 2011, Contribution of tracers for understanding the hydrodynamics of karstic 
aquifers crossed by allogenic rivers, Spain, in Elango, L, ed., Hydraulic Conductivity-Issues, Determination, and Applications: Rijeka, Croatia, InTech, p. 247-266. doi:10.5772/22093.

Shevenell, L., 1996, Analysis of well hydrographs in a karst aquifer: estimates of specific yields and continuum transmissivities: Journal of Hydrology, v. 174, no. 3-4, p. 331-355. doi:10.1016/0022-1694(95)02761-0.

Shuster, E.T., and White, W.B., 1971, Seasonal fluctuations in the chemistry of lime-stone springs: a possible means for characterizing carbonate aquifers: Journal of Hydrology, v. 14: p. 93-128. doi:10.1016/ 0022-1694(71)90001-1.

Urzendowski, L., 1993, Spectral Analysis of the Flow Behavior of Big Spring, Kings Canyon National Park, California. [M.S. thesis]: University of Nevada, Las Vegas, $122 \mathrm{p}$

White, W.B., 2002, Karst hydrology: recent developments and open questions. Engineering Geology, v. 65, no. 2-3, p. 85-105. doi:10.1016/ S0013-7952(01)00116-8.
White, W.B., 2003, Conceptual models for karstic aquifers: Speleogenesis and Evolution of Karst Aquifers, v. 1 no. 1 1. 16 p. (Re-published from: Palmer, A.N., Palmer, M.V., and Sasowsky, I.D., eds, 1999, Karst Modelling: Karst Waters Institute Special Publication 5, p. 11-16.)

Worthington, S.R.H., 1999, A comprehensive strategy for understanding flow in carbonate aquifers, in Palmer, A.N., Palmer, M.V., and Sasowsky, I.D., eds., Karst Modeling: Karst Waters Institute Special Publication 5, p. 3037.

Worthington, S.R.H., 2009, Diagnostic hydrogeologic characteristics of a karst aquifer (Kentucky, USA): Hydrogeology Journal, v. 17, p. 16651678. doi:10.1007/s10040-009-0489-0.

Worthington, S.R.H., and Ford, D.C., 2009, Self-organized permeability in carbonate aquifers: Groundwater, v. 47, p. 326-336. doi:10.1111/j. 1745-6584.2009.00551.x.

Yevjevich, V.M., ed., 1981, Karst Water Research Needs: Littleton, Colorado, Water Resources Publications, 266 p. 